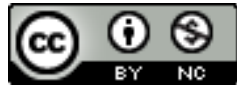

Jurnal Pendidikan Ilmu Pengetahuan Sosial Indonesia is licensed under

A Creative Commons Attribution-Non Commercial 4.0 International License.

\title{
DAMPAK SOSIAL SISTEM FULL DAY SCHOOL BAGI SISWA SEKOLAH DASAR
}

\author{
Mertika $^{1)}$, Frahasini²) \\ 1) Pendidikan Guru Sekolah Dasar, STKIP Singkawang, Singkawang, Indonesia \\ Email: mertika0526912gmail.com \\ 2) Pendidikan Guru Sekolah Dasar, STKIP Singkawang, Singkawang, Indonesia \\ Email:isinrizaalvin@gmail.com
}

\begin{abstract}
Abstrak. Tujuan penelitian ini adalah untuk mengetahui dan menganalisis dampak sosial system one day school bagi siswa sekolah dasar. Artikel ini merupakan hasil analisis berdasarkan literatur yang berkaitan dengan topik pembahasan. Model yang digunakan adalah studi pustaka atau literature review. Hasil penelaahan menunjukkan bahwa adanya dampak positif dan negatif dari diterapkannya system full day school bagi siswa sekolah dasar. Penerapan full day school lebih memiliki banyak dampak positif dibanding dampak negatifnya karena siswa hampir sepenuh hari menghabiskan waktu di sekolah semua yang siswa peroleh di dapat di sekolah sehingga siswa lebih terkontrol dibanding berada di lingkungan rumah karena sebagian dari siswa tidak mendapat perhatian dari orang tua jadi disitulah siswa dibimbing. Saran bagi Lembaga Pendidikan yang menerapkan system full day school agar mempersiapkan sarana dan prasarana dengan lebih matang agar proses kegiatan belajar mengajar dapat berjalan dengan lancar, kedua agar memperhatikan kesiapan fisik maupun psikis peserta didik dalam penyesuaian dengan sistem pembelajaran di sekolah.
\end{abstract}

Kata Kunci: Dampak Sosial, Full Day School

\section{Pendahuluan}

Pendidikan merupakan salah satu unsur yang sangat mendasar dalam kehidupan manusia. Karena itu setiap individu wajib untuk dididik sejak dini, baik melalui lembaga formal, informal, maupun nonformal. Orangtua sebagai lembaga pendidik primer juga memiliki peranan penting dalam hal mendidik seorang anak. Namun peran orang tua dari hari ke hari semakin berkurang terutama di daerah perkotaan, baik oleh kesibukan mereka atau pergaulan anak-anak yang kian bebas. Dengan demikian, orang tua tidak bisa mendidik anaknya secara maksimal.

Sekolah sebagai lembaga pendidikan formal diharapkan memiliki kualitas yang baik sehingga mampu memenuhi kebutuhan masyarakat dan dapat memberikan dampak yang positif dalam kehidupan sosial peserta didik. Dampak sosial merupakan sebuah perubahan akibat suatu kejadian, keadaan, kebijakan sehingga mengakibatkan perubahan baik yang bersifat positif maupun negatif bagi kehidupan sosial dan keadaan sosial. Fardani (2012:6) menyatakan bahwa dampak sosial adalah sebuah bentuk akibatatau pengaruh yang terjadi karena adanya sesuatu hal. Pengaruh yang dimaksud adalah pengaruh yang terjadi pada masyarakat.

Seiring dengan dinamika kehidupan yang kian menuntut kecepatan, ketepatan, kewaspadaan, perkembangan intelektual, emosional, spiritual dan kreatifitas siswa, metode konvensional dirasa belum dapat memenuhi kebutuhan pendidikan di masa sekarang dan mendatang sehingga muncullah konsep pendidikan baru yang dinamakan full day school (Wicaksono: 2017: 11). Kata full day school berasal dari Bahasa Inggris. Yang mana terdiri dari kata full mengandung arti penuh, dan day artinya hari. 
Full day mengandung arti sehari penuh. Full day juga berarti hari sibuk. Sedangkan school artinya sekolah (Haluti, 2017:197). Full day school atau sekolah sehari penuh merupakan kebijakan sekolah yang mewajibkan siswa hadir di sekolah mulai dari pagi hari hingga sore hari untuk melakukan kegiatan pembelajaran. Full day school merupakan kebijakan yang dikeluarkan oleh Kementerian Pendidikan dan kebuadayaan (Kemendikbud). Kemendikbud mengeluarkan kebijakan sekolah lima hari dalam satu minggu dan 8 jam belajar dalam satu hari mulai tahun ajaran 2017/2018. Hal itu tertuang dalam Peraturan Menteri Pendidikan dan Kebudayaan (Permendikbud) Nomor 23 Tahun 2017 tentang hari sekolah. (Irma dan Imran, 2019:46).

Untuk mempertegas kajian istilah, secara etimologis, kata Full Day School (FDS) berasal dari Bahasa Inggris. Full mengandung makna maksimal, penuh, banyak, dan Day mengandung makna hari. Jadi, pengertian Full Day secara harfiah memiliki arti sehari penuh. Full Day juga memiliki pengertian hari sibuk. Sedangkan School adalah terjemahan dari sekolah. Maka, pengertianFull Day School (FDS) adalah sekolah sepanjang hari penuh atau bisa disebut dengan proses kegiatan belajar mengajar (KBM) yang dilaksanakan sejak pukul 06.45-15.00 WIB. Pemberlakukan jam pelajaran yang cukup lama dibanding proses lainnya, maka program Full Day School dinilai lebih sempurna melayani kepentingan pembelajaran anak. Jam belajar yang cukup panjang juga akan memaksimal pengawasan sekolah terhadap anak didik (Rahem, 2017: 5).

Munculnya pendidikan dengan pembelajaran program full day school diharapkan menjadi alternatif yang dapat memenuhi tuntutan pendidikan di masa sekarang. Melalui pembelajaran program full day school, peserta didik dibekali dengan nilai-nilai agama atau moralitas yang tinggi sehingga mereka tidak menjadi korban arus informasi global. Peran full day school, mampu menanamkan kebiasaan hidup mandiri, terampil dan menjunjung tinggi nilai-nilai moralitas. Hal ini dapat dilakukan sebab integrasi dan interaksi yang terjadi antara peserta didik dengan guru dalam pembelajaran, terjadi lebih intens dibandingkan dengan sekolah reguler, sehingga kegiatan dan aktifitas peserta didik dapat dikendalikan sesuai dengan jadwal

yang telah ditentukan. Hal ini menunjukkan bahwa pengelolaan pembelajaran yang baik dan berkualitas akan mampu menentukan kualitas pembelajaran program full day school. Pengelolaan pembelajaran yang baik akan meningkatkan keberhasilan kualitas peserta didik (Wicksono, 2017: 11-12).

Berdasarkan beberapa pendapat di atas dapat ditarik simpulan bahwa full day schoolmerupakansekolah yang dalam pelaksanaan pembelajarannya dilakukan selama sehari penuh dari pagi hingga sore dengan sebagian waktunya digunakan untuk pelajatan yang suasananya informal, tidak kaku, menyenangkan bagi siswa dan membutuhkan kreatifitas dan inovasi dari guru. Sekolah dapat mengatur jadwal pelajaran dengan bebas dan leluasa, disesuaikan dengan bobot mata pelajaran dan ditambah dengan pendalaman materi. Oleh sebab itu dalam penelitian ini diberi judul: "Dampak sosial system full day school bagi siswa sekolah dasar

\section{Metode Penelitian}

Metode dalam penelitian ini adalah penelitian dengan studi pustaka. Penelitian kepustakaan dan studi pustaka/riset pustaka meski bisa dikatakan mirip akan tetapi berbeda. Studi pustaka adalah istilah lain dari kajian pustaka, tinjauan pustaka, kajian teoritis, landasan teori, telaah putsaka (literature review), dan tinjauan teoritis.

Penelitian kepustakaan adalah penelitian yang dilakukan hanya berdasarkan atas karya tertulis, termasuk hasil penelitian baik yang telah maupun yang belum dipublikasikan (Rifqy, 2012). Menurut Zed (2014) pada riset pustaka (library research), penelusuran pustaka tidak hanya untuk langkah awal menyiapkan kerangka penelitian (research design) akan tetapi sekaligus memanfaatkan sumber-sumber perpustakaan untuk memperoleh data penelitian. Dalam penelitian ini, 
peneliti menganalisi berbagai artikel yang berkaitan dengan topik pembahasan.

\section{HASIL DAN PEMBAHASAN}

Tiga alasan yang melandasi lahirnya sistem pembelajaran full day school. Pertama, mengurangi pengaruh negatif dari luar pada anak usai sekolah. Kedua, rentan waktu belajar di sekolah relatif lebih lama sehingga memaksa siswa belajar mulai pagi hingga sore hari, sehingga waktu belajar di sekolah lebih efektif dan efisien. Ketiga, sangat membantu orang tua siswa terutama yang sibuk bekerja. Full day school memiliki dua tujuan yang mendasar. Pertama, mengembangkan mutu pendidikan. Kedua, salah satu upaya pembentukan akidah dan akhlak siswa dan menanamkan nilai-nilai positif. Ketiga, memberikan dasar yang kuat dalam belajar pada segala aspek yaitu perkembangan intelektual, fisik, sosial dan emosional (Wicaksono, 2017:14).

Latarbelakangpara orang tua tertarik untuk memasukkan anaknya ke Full Day School (FDS), antara lain yaitu semakin meluasnya kaum ibu yang bekerja di luar rumah dan mereka banyak yang mempunyai anak berusia di bawah 7 tahun, membludaknya jumlah anak-anak usia pra-sekolah yang ditampung di sekolah-sekolah milik publik, makin tingginya pengaruh televisi dan makin meningkatnya mobilitas para orang tua, serta segala kemajuan dan modernitas yang mulai berkembang pesat di semua aspek kehidupan. Pilihan terhadap sekolah yang memberlakukan pembelajaran lebih panjang menjadi pilihan sangata rasional. Orang tua memiliki harapan, jaminan anak lebih aman dan mendapatkan sentuhan pendidikan juga lebih maksimal. Desakan kesibukan dalam sebuah tatanan negara, memaksa sejumlah pihak untuk menentukan pilihan sangat cepat.

Dikutip dalam (Tambunan, Huda, Degeng 2017: 848-848), "Full Day School tentu tak bisa diterapkan untuk semua sekolah, walaupun telah dikatakan oleh Huda (2010:57) bahwa otonomi di bidang pendidikan merupakan wahana baru dalam rangka mengatasi berbagai permasalahan kualitas pendidikan yang terjadi diindonesia dengan konsep memandirikan lembaga pendidikan dalam mengelola sumber daya yang dimilikinya. Pendapat tersebut dipertegas oleh Degeng, Utari, dan Akbar (2016) bahwa setiap daerah memiliki nilai-nilai kearifan lokal yang menjadi ciri khas di suatu daerah tersebut.Contoh kecil keragaman di sekolah adalah kelas sebagai lingkungan siswa memiliki karakteristik yang berbeda-beda karenamemiliki siswa yang berbeda-beda pula.

Keragaman kelas dapat diperoleh dari keragaman latar budaya, ras, suku, agama, etnik, jenis kelamin, tingkat ekonomi orangtua, dan lain-lain (Degeng, Pranan dari, dan Hanurawan, 2016). Dalam sistem Full Day School berjalan beriringan dengan terbentuknya dampak positif dan negatif yang dialami bagi sebagian atau seluruh masyarakat yang menerapkan pola pembelajaran tersebut. Sementara jenis pembelajaran yang diterapkan menjadi penentu dalam keberhasilan proses pembelajaran di sekolah (Sudana, Muniroh, Hitipeuw, dan Hidayah, 2016). Berdasarkan pendapat tersebut, berikut peneliti rangkum beberapa dampak positif dan negative yang dapat ditimbulkan dari penerapan system full day school bagi siswa sekolah dasar.

\section{Dampak Positif Sistem Full Day School}

Baharudin (2010: 225) menyatakan bahwa full day school memiliki keunggulan dan beberapa nilai tambah. Pertama, anak memperoleh pendidikan umum antisipasi terhadap perkembangan ilmu pengetahuan. Kedua, Anak mendapatkan pendidikan kepribadian yang bersifat antisipatif terhadap perkembangan sosial budaya. Ketiga, Potensi anak tersalurkan melalui kegiatan ekstrakurikuler yang diadakan sekolah. Keempat, Potensi anak tersalurkan melalui kegiatan ekstrakurikuler yang diadakan sekolah. Sedangkan Cryan dan Others (dalam Iwan Kuswandi, 2013:54) menyatakan bahwa full day school memberikan efek positif karena anak-anak akan lebih banyak belajar dari pada bermain yang bermuara pada produktivitas tinggi, siswa menunjukkan sikap yang lebih 
positif, terhindar dari penyimpangan karena seharian berada di kelas dan dalam pengawasan guru. Hasil penelitian Irma dan Imran (2019: 48) menyatakan selama diterapkannya sistem full day scool dampak positifnya itu sendiri yaitu dalam satu minggu siswa dan guru dapat libur sekolah selama 2 hari sehingga siswa dan guru dapat menghabiskan wkatu diakhir pekan bersama keluarga hal ini dikarenakan jam belajar bertambah dari pagi sampai sore hari yaitu pada pukul 06.45 - 15.30 selama 5 hari. Sistem ini juga memiliki kelebihan yang memudahkan orangtua yang sibuk bekerja sehingga sekolah full day menjadi pilihan bagi orangtua terhadap pendidikan anaknya karena dengan full day lebih terkontrol kegiatan peserta didik mengarah kepada aktivitas dan pembiasaanpembiasaan baik seperti bimbingan ibadah. Sistem full day juga merupakan solusi terhadap perilaku negatif peserta didik (Suranto \& Seftiana, dalam Triyana dkk, 2018: 1552). Penelitian Septianawati dan Nurhamlin (2019:1012) menunjukkan bahwa ada dua dampak positif full day school bagi siswa, pertama yaitu proses pembelajaran menjadi lebih dalam dan rinci. Proses pembelajaran menjadi lebih maksimal dikarenakan fasilitas sekolah yang lengkap serta waktu belajar yang lebih lama dibandingkan dengan sekolah biasa sehingga guru dapat lebih leluasa untuk mengajarkan materi secara lebih jelas dan rinci. Yang kedua, tidak perlu mengikuti kegiatan bimbingan belajar tambahan diluar proses kegiatan belajar megajar di sekolah. Pada sekolah dengan full day school yang pada dasarnya siswa berada di sekolah dari pagi hingga sore hari, memiliki waktu yang lebih banyak sehingga pihak sekolah atau guru yang bersangkutan dapat dengan sedemikian rupa untuk menyusun kegiatan pembelajaran. Sehingga semua yang dibutuhkan oleh siswa telah terpenuhi tanpa harus mengikuti bimbingan belajar seusai sekolah. Siswa dan guru juga bisa bertemu di sekolah lebih lama selain jam pelajaran, maka peluang siswa untuk bertanya mengenai materi yang kurang dipahaminya menjadi lebih banyak
Penerapan full day school lebih memilki banyak dampak positif dibanding dampak negatifnya karena siswa hampir sepenuh hari menghabiskan waktu di sekolah semua yang siswa peroleh di dapat di sekolah sehingga siswa lebih terkontrol dibanding berada di lingkungan rumah karena sebagian dari siswa tidak mendapat perhatian dari orang tua jadi disitulah siswa dibimbing.

\section{Dampak Negatif Sistem Full Day School}

Dampak negative penerapan system full day school dalam pembelajaran siswa yaitu sulitnya penyesuaian terhadap siswa ketika pembelajaran di dalam kelas terutama pada jamjam terakhir, siswa biasanya mudah mengantuk dan lelah sehingga kontentrasinya menurun disitulah bagaimana peran seorang guru sangat penting dalam menyiasati keadaan kelas agar pembelajaran tetap nyaman dan tidak kaku (Irma dan Imran, 2019: 48).

Penelitian sejenis dilakukan oleh Rizky (2015) menyimpulkan bahwa problematika yang sering terjadi dalam pelaksanaan pembelajaran sistem full day school diantaranya yang adalah masih ditemukan siswa yang belum mampu menyesuaikan diri dengan jam tambahan yang diberlakukan oleh sekolah dan adanya sebagian kecil siswa yang merasa kelelahan atau bosan karena seharian berada di sekolah. Penelitian tersebut menunjukkan bahwa full day school masih memiliki kelemahan dalam pelaksanaannya walaupun banyak keunggulan. Hal tersebut harus dapat diatasi oleh pengelola full day school di sekolah agar dalam pelaksanaannya dapat berjalan lancar.

Selain dampak negatif berupa kurang mampunya siswa dalam penyesuaian dengan system pembelajaran full day school, dalam penelitian yang dilakukan oleh Septianawati dan Nurhamlin (2019: 10-12), didapati dua dampak negative yang timbul dari system full day school bagi siswa. Pertama, siswa menjadi kelelahan karena jadwal sekolah yang padat. Meskipun sistem full day school memiliki banyak 
manfaat terhadap siswa, namun tidak dapat di sangkal bahwa system full day school juga memiliki dampak negatif. Salah satunya yaitu siswa menjadi kelelahan di karenakan jadwal sekolah yang padat. Kedua, bersosialisasi dengan lingkungan tempat tinggal menjadi berkurang. Hal ini karena sebagaian besar waktu dihabiskan di sekolah. Siswa pada umumnya tidak dapat melakukan kegiatan dengan bebas seusai pulang sekolah di karenakan waktu yang terbatas.

\section{IV.KESIMPULAN}

Berdasarkan masalah dan tujuan khusus penelitian, maka untuk menjawab permasalahan penelitian berdasarkan hasilpenelitian dan analisisi data dapat disimpulkan sebagai berikut:

1. Pengaruh negatif dari luar sekolah dapat diminimalisir

2. Anak-anak jelas akan medapatkan metode pembelajaran yang bervariasi dan lain daripada sekolah dengan program reguler.

3. Orang tua tidak merasa khawatir, karena anak- anak mereka berada seharian di sekolah yang berarti ada mengawasi mereka para guru dan sebagian waktu anak untuk belajar.

\section{DAFTAR PUSTAKA}

Baharuddin. (2010). Pendidikan dan Psikologi Perkembangan. Jogjakarta: Ar-Ruzz Media.

Fardani, Andi. (2012). Dampak Sosial Keberadaan PT Vale Indonesia Tbk Terhadap Kehidupan Masyarakat (Studi Kasus Sorowako Kecamatan Nuha Kabupaten Luwu Timur). Universitas Hasanudin: Jurusan Sosiologi FISIP

Irma, Ade dan Imran. (2019). Dampak Penerapan Full Day School Pada Pembelajaran Siswa di SMP Negeri 14 Palu. Jurnal Edu Civic. 5 (1), 46-53.

Haluti, Ismail M. (2017).

Implementasi Pendidikan Karakter dalam Sistem Full Day School di MIM Unggulan Kota Gorontalo. Jurnal Ilmiah AL- Jauhari (JIAJ). 2(2), 195-210.
Rahem, Zaitur. (2017). Dampak Sosial pemberlakuan Full Day School (Menimbang Mafsadat-Maslahat Permendikbud 23/2017 dan Perpres 87/2017). Al- Murabbi: Jurnal Pendidikan Agama Islam. 3(1), 1-12. 